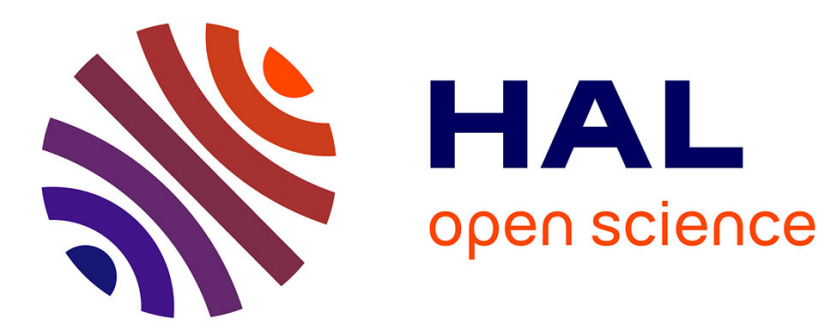

\title{
Reply to Patel et al .: Tempering the Clinical Effects of Early Myeloid-derived Suppressor Cell Expansion in Severe Sepsis and Septic Shock
}

Fabrice Uhel, Christophe Camus, Arnaud Gacouin, Jean-Marc Tadié, Yves Le Tulzo, Mikael Roussel, Karin Tarte

\section{To cite this version:}

Fabrice Uhel, Christophe Camus, Arnaud Gacouin, Jean-Marc Tadié, Yves Le Tulzo, et al.. Reply to Patel et al .: Tempering the Clinical Effects of Early Myeloid-derived Suppressor Cell Expansion in Severe Sepsis and Septic Shock. American Journal of Respiratory and Critical Care Medicine, 2018, 197 (5), pp.678-679. 10.1164/rccm.201709-1854LE . hal-01721730

\section{HAL Id: hal-01721730 \\ https://hal-univ-rennes1.archives-ouvertes.fr/hal-01721730}

Submitted on 2 Mar 2018

HAL is a multi-disciplinary open access archive for the deposit and dissemination of scientific research documents, whether they are published or not. The documents may come from teaching and research institutions in France or abroad, or from public or private research centers.
L'archive ouverte pluridisciplinaire HAL, est destinée au dépôt et à la diffusion de documents scientifiques de niveau recherche, publiés ou non, émanant des établissements d'enseignement et de recherche français ou étrangers, des laboratoires publics ou privés. 


\section{Reply to: Tempering the Clinical Effects of Early Myeloid Derived Suppressor Cell Expansion in Severe Sepsis and Septic Shock}

Fabrice Uhel $^{1,2,3}$, Christophe Camus ${ }^{1,2}$, Arnaud Gacouin ${ }^{1,2}$, Jean-Marc Tadié , $^{1,2,3}$, Yves Le Tulzo ${ }^{1,2,3}$, Mikael Roussel ${ }^{3}$, and Karin Tarte ${ }^{3}$, on behalf of all the authors.

${ }^{1}$ Centre Hospitalier Universitaire de Rennes, Maladies Infectieuses et Réanimation Médicale, Rennes, France

${ }^{2}$ Institut National de la Santé et de la Recherche Médicale, Centre d'Investigation Clinique-1414, Rennes, France

${ }^{3}$ Institut National de la Santé et de la Recherche Médicale, Unité Mixte de Recherche U917, Université Rennes1, Etablissement Français du Sang Bretagne, Centre Hospitalier Universitaire de Rennes, Laboratoire Suivi Immunologique des Thérapeutiques Innovantes, Rennes, France

\section{Author disclosures}

The authors declare no competing financial interest

\section{Authors' contribution}

Wrote the paper: FU, KT. Critically revised the manuscript: all authors. 
We are grateful to Dr. Patel and colleagues for their interest in our study on the phenotype, suppressive activity, origin, and clinical impact of myeloid-derived suppressor cells (MDSCs) in septic patients (1). If evidence for a causal relationship between expansion of granulocytic (G-)MDSCs and development of secondary infections in sepsis is inherently hampered by the observational nature of our study, our work provides new insights supporting a role of MDSC expansion in sepsisassociated immune dysfunction.

Dr. Patel and colleagues raise concerns about the sample size of our study, which may result in insufficient power, thereby challenging our conclusions on the impact G-MDSC expansion on clinical outcome. The hazard ratio for the development of nosocomial infection in septic patients with $>36 \%$ G-MDSCs was 2.83 (95\% confidence interval $1.18-8.11)$, representing a statistically significant result, which has the limitation of type-I error ( $\alpha$ risk $=5 \%$ ), but not type-II error. In addition, a post hoc analysis confirmed that the size of our population (94 septic patients) allowed us to demonstrate a significant difference between patients developing or not nosocomial infections (alpha risk set at $5 \%$ ) with a power of $97 \%$. Finally, the size of our cohort is consistent with previous studies that could demonstrate a link between sepsis-induced immunologic impairments and the development of nosocomial infections $(2,3)$. Moreover, a recent study reporting a similar association between expansion of G-MDSCs and an increased incidence of nosocomial infections in 74 surgical patients admitted to the ICU for sepsis is in line with our results and strengthens our conclusions (4). Therefore, we believe that our study is methodologically robust. 
Given their lack of any specific pattern, we have not detailed in our leading study the causative pathogens involved in nosocomial infections. However, a rapid overview of responsible organisms (Table 1) confirms that they correspond to pathogens classically involved in nosocomial infection, as recently described in a large cohort of ICU patients (5).

Finally, Dr. Patel and colleagues challenge the clinical characteristics of our septic and non-septic ICU patient cohorts. We agree that mortality of septic patients was lower than expected from previous large epidemiological studies. However, our results are in agreement with the regular decrease in sepsis mortality observed in the past two decades, mainly explained by an earlier sepsis recognition and a widespread integration of best clinical practices (5). Moreover, because MDSCs have been initially described in patients with malignancies, and because we wanted to study their suppressive properties, we decided to exclude patients with cancer and preexisting immune suppression from our cohort. In many studies, malignancies and immunosuppression have been shown to be major risk factors of mortality during sepsis $(6,7)$. Finally, a large epidemiological study recently underlined that ICUacquired infections contributed only modestly to overall mortality in septic patients (8). Thus, mortality and secondary infections should be considered as different outcome endpoints regarding the clinical impact of MDSCs. In agreement, as discussed by Dr. Patel, we found no difference in MDSC subsets between septic shock and severe sepsis patients, despite huge differences in clinical outcome. Of note, no clinical conclusion has been proposed based on our very small non-septic ICU patient cohort but their high mortality rate further exclude that the G-MDSC expansion specifically observed in septic patients could be related to a worse prognosis. 
To conclude, our study paves the way for investigations in large patient cohorts to further ascertain the relationship between MDSCs and nosocomial infection in sepsis. Our findings provide first mechanistic insights into the roles of MDSCs during sepsis and their potential as a therapeutic target. 


\section{Table}

Table 1. Causative pathogens of hospital-acquired infections in patients admitted for sepsis

\begin{tabular}{|c|c|c|}
\hline \multicolumn{2}{|c|}{ Gram negative bacteria } & $11(47.8 \%)$ \\
\hline & Pseudomonas aeruginosa & 4 \\
\hline & Escherichia coli & 2 \\
\hline & Enterobacter cloacae & 1 \\
\hline & Stenotrophomonas matophilia & 1 \\
\hline & Klebsiella pneumoniae & 1 \\
\hline & Serratia marcescens & 1 \\
\hline & Bacteroides species & 1 \\
\hline \multicolumn{2}{|c|}{ Gram positive bacteria } & $8(34.8 \%)$ \\
\hline & Coagulase negative staphylococcus & 3 \\
\hline & Enterococcus faecalis & 2 \\
\hline & Staphylococcus aureus & 1 \\
\hline & Corynebacterium species & 1 \\
\hline & Clostridium difficile & 1 \\
\hline \multirow[t]{2}{*}{ Fungi } & & $3(13.0 \%)$ \\
\hline & Candida albicans & 3 \\
\hline \multirow[t]{2}{*}{ Virus } & & $1(4.3 \%)$ \\
\hline & Varicella zoster virus & 1 \\
\hline
\end{tabular}




\section{References}

1. Uhel F, Azzaoui I, Gregoire M, Pangault C, Dulong J, Tadie J-M, Gacouin A, Camus C, Cynober L, Fest T, Le Tulzo Y, Roussel M, Tarte K. Early Expansion of Circulating Granulocytic Myeloid-derived Suppressor Cells Predicts Development of Nosocomial Infections in Patients with Sepsis. Am J Respir Crit Care Med 2017;196:315-327.

2. Monneret $G$, Lepape A, Voirin N, Bohé J, Venet F, Debard A-L, Thizy $H$, Bienvenu J, Gueyffier F, Vanhems P. Persisting low monocyte human leukocyte antigen-DR expression predicts mortality in septic shock. Intensive Care Med 2006;32:1175-1183.

3. Grimaldi D, Louis S, Pène F, Sirgo G, Rousseau C, Claessens YE, Vimeux L, Cariou A, Mira JP, Hosmalin A, Chiche JD. Profound and persistent decrease of circulating dendritic cells is associated with ICU-acquired infection in patients with septic shock. Intensive Care Med 2011;37:1438-1446.

4. Mathias B, Delmas AL, Ozrazgat-Baslanti T, Vanzant EL, Szpila BE, Mohr AM, Moore FA, Brakenridge SC, Brumback BA, Moldawer LL, Efron PA, and the Sepsis, Critical Illness Research Center Investigators. Human Myeloid-derived Suppressor Cells are Associated With Chronic Immune Suppression After Severe Sepsis/Septic Shock. Ann Surg 2017;265:827-834.

5. Kaukonen K-M, Bailey M, Suzuki S, Pilcher D, Bellomo R. Mortality Related to Severe Sepsis and Septic Shock Among Critically III Patients in Australia and New Zealand, 2000-2012. JAMA 2014;311:1308.

6. Daviaud F, Grimaldi D, Dechartres A, Charpentier J, Geri G, Marin N, Chiche J$D$, Cariou A, Mira J-P, Pène F. Timing and causes of death in septic shock. Annals of Intensive Care 2015;5:16.

7. Poutsiaka DD, Davidson LE, Kahn KL, Bates DW, Snydman DR, Hibberd PL. Risk factors for death after sepsis in patients immunosuppressed before the onset of sepsis. Scand J Infect Dis 2009;41:469-479.

8. van Vught LA, Klein Klouwenberg PMC, Spitoni C, Scicluna BP, Wiewel MA, Horn J, Schultz MJ, Nürnberg P, Bonten MJM, Cremer OL, van der Poll T, MARS Consortium. Incidence, Risk Factors, and Attributable Mortality of Secondary Infections in the Intensive Care Unit After Admission for Sepsis. JAMA 2016;315:1469-1479. 